\title{
Identification and Target-Modification of SL-BBI: A Novel Bowman-Birk Type Trypsin Inhibitor from Sylvirana latouchii
}

\author{
Xi Chen ${ }^{1,+}$, Dong Chen ${ }^{1,+}$, Linyuan Huang ${ }^{2}$, Xiaoling Chen ${ }^{1}$, Mei Zhou ${ }^{1}{ }^{\oplus}$, Xinping Xi ${ }^{1}$, \\ Chengbang Ma ${ }^{1, *}$, Tianbao Chen ${ }^{1}(\mathbb{D})$ and Lei Wang ${ }^{1(D)}$ \\ 1 Natural Drug Discovery Group, School of Pharmacy, Queen's University Belfast, Belfast BT9 7BL, UK; \\ xchen27@qub.ac.uk (X.C.); dchen03@qub.ac.uk (D.C.); x.chen@qub.ac.uk (X.C.); m.zhou@qub.ac.uk (M.Z.); \\ x.xi@qub.ac.uk (X.X.); t.chen@qub.ac.uk (T.C.); l.wang@qub.ac.uk (L.W.) \\ 2 School of Life Sciences and Technology, China Pharmaceutical University, Nanjing 211198, China; \\ huangly@cpu.edu.cn \\ * Correspondence: c.ma@qub.ac.uk; Tel.: +44-28-9097-1673 \\ + The authors contributed equally to this work.
}

Received: 24 July 2020; Accepted: 27 August 2020; Published: 28 August 2020

\begin{abstract}
The peptides from the ranacyclin family share similar active disulphide loop with plant-derived Bowman-Birk type inhibitors, some of which have the dual activities of trypsin inhibition and antimicrobial. Herein, a novel Bowman-Birk type trypsin inhibitor of the ranacyclin family was identified from the skin secretion of broad-folded frog (Sylvirana latouchii) by molecular cloning method and named as SL-BBI. After chemical synthesis, it was proved to be a potent inhibitor of trypsin with a Ki value of $230.5 \mathrm{nM}$ and showed weak antimicrobial activity against tested microorganisms. Modified analogue K-SL maintains the original inhibitory activity with a Ki value of $77.27 \mathrm{nM}$ while enhancing the antimicrobial activity. After the substitution of active P1 site to phenylalanine and $\mathrm{P} 2$ ' site to isoleucine, F-SL regenerated its inhibitory activity on chymotrypsin with a Ki value of $309.3 \mathrm{nM}$ and exhibited antiproliferative effects on PC-3, MCF-7 and a series of non-small cell lung cancer cell lines without cell membrane damage. The affinity of F-SL for the $\beta$ subunits in the yeast $20 \mathrm{~S}$ proteasome showed by molecular docking simulations enriched the understanding of the possible action mode of Bowman-Birk type inhibitors. Further mechanistic studies have shown that F-SL can activate caspase 3/7 in H157 cells and induce apoptosis, which means it has the potential to become an anticancer agent.
\end{abstract}

Keywords: natural molecules; Bowman-Birk type inhibitor; ranacyclin; antimicrobial; anticancer

\section{Introduction}

Serine protease inhibitors can regulate a variety of physiological reactions in the body by preventing unnecessary proteolytic functions. More than 1500 natural serine protease inhibitors from animal tissues and bodily fluids, plants, bacteria, fungi and viruses have been found at present. Among them, Bowman-Birk inhibitor (BBI) is a peptide family rich in cysteine and supported by seven intramolecular disulphide bonds, with dual inhibitory activity of trypsin and chymotrypsin due to its two independent reaction ring exposure at the molecular terminal [1]. The more concise BBI sequences are usually within 20 amino acids and contain an 11-residue active reaction loop, almost all of which are present in amphibian skin secretions and were generalised as the ranacyclin family [2]. 
Substantial evidence suggests that trypsin inhibitor peptides own prominent activity in protease inhibitory [3], antimicrobial [4] and anticarcinogenic [5-9], few of which are even considered as potent immunomodulators with hemopoietic actions [10]. Ranacyclin is the unique family of serine protease inhibitors known from amphibian skin secretions and usually has the dual activities of trypsin inhibition and antibacterial [2,11] to combat the invasion of foreign invasive pathogens. Additionally, the proliferation, migration, spread and invasion of cancer cells are complex pathological processes involving multiple proteolytic enzymes [12]. Although the specific mechanism of BBI as an anticancer factor is unclear, protease inhibition has been shown to reverse the development in the early stages of tumorigenesis. The broad-spectrum anti-proliferation effects by BBIs act on cancer types such as lung [5,13], prostate [5,8], colon [6], breast [9,14,15], and oral [16]. It is particularly worth mentioning that the few side effects $[5,13,15,17]$ and radioprotection $[18,19]$ to normal mammalian cells establish the cancer chemoprevention properties of such peptides. Many types of researched protease inhibitors also have gained huge significance as potential pharmacological tools in cancer treatment [15,20-22] may be through inhibiting the activity of proteasome $20 S$ and promotes apoptosis through ROS-induced mitochondrial damage following proteasome inhibition [14]. Furthermore, BBI can also affect the expression of certain oncogenes, the activity of certain proteolytic reactions (increased activity of this response in tissues exposed to the cancer-induced factor) and reverse the initial phase of malignant transformation induced by radiation and chemical carcinogen [23]. Inhibitors of BBI families have been confirmed to bind to classical bradykinin and its analogues as a protective pathway to against the cleavage of plasmatic serine proteases, leading to an increase in the half-life of bradykinin [24].

In this research, a novel Bowman-Birk type protease inhibitor named SL-BBI was purified and characterised from the skin secretion of Sylvirana latouchii. While the biofunction of SL-BBI was estimated, we carried out targeted modifications to promote the antimicrobial efficacy based on maintaining trypsin inhibition and increase anticancer activity, respectively. Both analogues, K-SL and F-SL, produced the expected promotion after functional assessment.

\section{Materials and Methods}

\subsection{Acquisition of Sylvirana latouchii Skin Secretions}

Adult broad-folded frogs, Sylvirana latouchii (sex undetermined, $n=5,3-5 \mathrm{~cm}$ snout-vent length) were captured in Fujian Province of China and then settled into a purpose-designed amphibian facility at $18-25^{\circ} \mathrm{C}$ under $12 \mathrm{~h} / 12 \mathrm{~h}$ light/dark cycled period. Skin secretion was collected by gentle transdermal electrical stimulation as the previous report [25] and rinsed off from the skin using deionised water. After lyophilisation, skin secretions were stored at $-20{ }^{\circ} \mathrm{C}$ for later use.

The study was performed according to the guidelines in the UK Animal (Scientific Procedures) Act 1986, project license PPL 2694, issued by the Department of Health, Social Services and Public Safety, Northern Ireland. Procedures had been vetted by the IACUC of Queen's University Belfast and approved on 1 March 2011.

\section{2. "Shot-gun" Cloning of SL-BBI Precursor-Encoding cDNA}

The biosynthetic precursor cDNA of SL-BBI was obtained as previously described [25]. Briefly, the Dynabeads ${ }^{\circledR}$ mRNA DIRECT ${ }^{\mathrm{TM}}$ Kit (Dynal Biotech, Merseyside, UK) was used to isolate the mRNA from the lyophilised skin secretion. The first-strand cDNA was synthesised by the BD SMART ${ }^{\mathrm{TM}}$ RACE cDNA Amplification Kit (BD Bioscience Clontech, UK) and used to construct the cDNA library through 3' RACE-PCR. For SL-BBI, the 3'-RACE reactions employed a NUP primer (supplied with the kit) and a degenerate sense primer (3'-RACE: 5'-GAWYYAYYHRAGCCYAAADATGTTCA-3', $\mathrm{R}=\mathrm{A} / \mathrm{G}, \mathrm{V}=\mathrm{A} / \mathrm{C} / \mathrm{G}, \mathrm{N}=\mathrm{A} / \mathrm{C} / \mathrm{T} / \mathrm{G}, \mathrm{Y}=\mathrm{C} / \mathrm{T}, \mathrm{S}=\mathrm{C} / \mathrm{G}, \mathrm{W}=\mathrm{A} / \mathrm{T}$ ) was designed based on the highly conserved nucleic acid sequences of the $5^{\prime}$-untranslated region of the protease inhibitory peptide published previously. The purified products were cloned by pGEM $^{\circledR}$-T Easy Vector Kit (Promega 
Corporation, Madison WI, USA) and sequenced through an ABI3730 automated sequencer (Applied Biosystems, Foster City, CA, USA).

\subsection{Isolation and Structural Analysis of SL-BBI}

Lyophilised skin secretions after the dissolution were used for isolation and identification of SL-BBI through a reverse-phase high-performance liquid chromatography (HPLC) fractionation system (Waters, Milford, MA, USA) over $240 \mathrm{~min}$ as previously reported [25]. Each fraction was analysed by a matrix-assisted laser desorption ionisation time-of-flight (MALDI-TOF) mass spectrometer (Voyager DE, PerSeptive Biosystems, Foster City, CA, USA), and the structure of selected peptide was confirmed by an LCQ-Fleet electrospray ion-trap mass spectrometer (Thermo Fisher Scientific, San Jose, CA, USA) through MS/MS fragmentation.

\subsection{Solid-Phase Peptide Synthesis of SL-BBI and Its Analogues}

After the confirmation of the sequence of the novel peptide from the translation of cloned cDNA and analyse of skin secretion samples, SL-BBI and two designed analogues (K-SL and F-SL) were chemically synthesised by Fmoc solid-phase peptide synthesis using a Tribute ${ }^{\circledR}$ peptide solid-phase synthesiser (Protein Technologies, Inc, Tucson, AZ, USA) as previously reported [25]. The synthetic peptides were subjected to functional assessment after purified and identified by RP-HPLC and MALDI-TOF mass spectrometry.

\subsection{Secondary Structure Analysis through Circular Dichroism (CD)}

The secondary structure of SL-BBI and its analogues in $10 \mathrm{mM}$ ammonium acetate and $50 \%$ TFE in $10 \mathrm{mM}$ ammonium acetate buffer respectively were detected by a JASCO J-815 CD spectrometer (Jasco, Essex, UK) across the wavelength range of 190-250 $\mathrm{nm}$ and predicted by an online software BeStSel (http://bestsel.elte.hu) according to the previous report [25].

\subsection{Trypsin and Chymotrypsin Inhibition Assay}

Ten microliters of trypsin/chymotrypsin (Sigma Aldrich, Dorset, UK) working solution $(0.1 \mu \mathrm{M}$ in $1 \mathrm{mM} \mathrm{HCl}$ ) was added into the wells of a black micro-titre plate with corresponding substrate and peptide replicates (0.1-100 $\mu \mathrm{M}$ ) in $10 \mathrm{mM}$ phosphate buffer (final volume $210 \mu \mathrm{L}$ ). Additionally, Phe-Pro-ArgNHMec (Bachem, Cambridge, UK) and Succinyl-Ala-Ala-Pro-Phe-NHMec (Bachem, Cambridge, UK) were performed as substrates for trypsin and chymotrypsin, respectively. The fluorescence intensity of NHMec was monitored at $37^{\circ} \mathrm{C}$ continuously for $30 \mathrm{~min}$ by a FLUOstar OPTIMA multi-well plate reader (BMG Labtech, Ortenberg, Germany) at wavelengths of $460 \mathrm{~nm}$ for emission and $395 \mathrm{~nm}$ for excitation. The inhibition curves of different protease were plotted using the Morrison equation and non-linear regression analysis, which were showed as outlined before [26].

\subsection{Minimum Inhibitory Concentration (MIC) and Minimum Bactericidal Concentration (MBC) Assays}

Antimicrobial activity of the synthetic peptides was assessed by determination of MIC/MBC on Escherichia coli (ATCC 11775), Staphylococcus aureus (ATCC 12600), Candida albicans (NCYC 1467) and methicillin-resistant Staphylococcus aureus (MRSA) (NCTC 12493) according to the previous report [25]. Briefly, the test microorganism was inoculated in Mueller Hinton Broth (MHB) medium and incubated overnight at $37^{\circ} \mathrm{C}$. Then the subculture was performed until the optical density (OD) reached the logarithmic growth phase and diluted to $1 \times 10^{6}$ colony forming units (CFU)/mL for bacteria and $1 \times 10^{5} \mathrm{CFU} / \mathrm{mL}$ for fungus obtained. The synthetic peptides with the concentration from 1 to $512 \mu \mathrm{M}$ were double diluted by PBS. Five replications of sterile control, vehicle control and growth control were set as $100 \mu \mathrm{L} \mathrm{MHB/well,} 100 \mu \mathrm{L} 1 \%$ PBS with subculture solution/well and $100 \mu \mathrm{l}$ subculture solution/well, respectively. The 96 -well plate was incubated at $37{ }^{\circ} \mathrm{C}$ overnight. The absorbance of each well at $550 \mathrm{~nm}$ was measured by Synergy HT plate reader (Biotech, Minneapolis, MN, 
USA). The minimum bactericidal concentration was detected by sub-culturing treated samples onto Mueller-Hinton agar (MHA) plate for another eighteen hours at $37^{\circ} \mathrm{C}$.

\subsection{MTT Cell Viability and LDH (Lactate Dehydrogenase) Cytotoxicity Assay}

MTT (3-(4, 5-dimethylthiazol-2-yl)-2, 5-diphenyltetrazolium bromide) cell viability assay was performed to evaluate the cell proliferation inhibitory rate of synthetic peptides in a series of human cell lines: PC-3 (ATCC ${ }^{\circledR}$ CRL-1435 ${ }^{\mathrm{TM}}$ ), H157 (RRID: CVCL_0463), H460 (ATCC ${ }^{\circledR}$ HTB-177 ${ }^{\mathrm{TM}}$ ), H838 (ATCC ${ }^{\circledR}$ CRL-5844 ${ }^{\mathrm{TM}}$ ), H23 (ATCC ${ }^{\circledR}$ CRL-5800 ${ }^{\mathrm{TM}}$ ), MCF-7 (ATCC ${ }^{\circledR}{ }^{\mathrm{HTB}}-22^{\mathrm{TM}}$ ), HCT116 (ATCC ${ }^{\circledR}$ CCL-247 ${ }^{\mathrm{TM}}$ ), U251MG (ECACC-09063001) and HMEC-1 (ATCC ${ }^{\circledR}$ CRL-3243 ${ }^{\mathrm{TM}}$ ) which was detailed in the previous report [5].

Pierce LDH Cytotoxicity Assay Kit (Thermo Fisher Scientific, Loughborough, UK) was used to detect the amount of LDH released from H157, H460, H1838 and H23 cells. $1 \times 10^{4}$ cell per $100 \mu \mathrm{L}$ of final cell suspension was deemed to be ideal in each well of a 96-well plate. After $24 \mathrm{~h}$ incubation $\left(37^{\circ} \mathrm{C}, 5 \% \mathrm{CO}^{2}\right)$, vehicle control and different concentration of sample solution were loaded on the plate which was further incubated for $24 \mathrm{~h} .10 \mu \mathrm{L} 10 \times$ Lysis Buffer was added as Maximum LDH Activity control for $45 \mathrm{~min}$ and $10 \mu \mathrm{L}$ water was added as Spontaneous LDH Activity control for the same time. $50 \mu \mathrm{L}$ aliquots of each well were transferred to a well of a fresh 96-well plate and mixed with $50 \mu \mathrm{L}$ of Reaction Mixture. After incubation for $30 \mathrm{~min}$ (room temperature, lightless), stop solution ( $50 \mu \mathrm{L} /$ well) was added to stop the reaction. The absorbance values at $490 \mathrm{~nm}$ and $680 \mathrm{~nm}$ were measured by Synergy HT plate reader (Biotech, Minneapolis, MN, USA).

\subsection{Haemolysis Activity Assay}

$4 \%(v / v)$ suspensions of horse erythrocytes (TCS Biosciences, Botolph Claydon, Buckingham, UK) in phosphate-buffered saline (PBS) was used to evaluate haemolysis activity by incubating with different concentration of synthetic peptides from $1 \mu \mathrm{M}$ to $512 \mu \mathrm{M}$ at $37^{\circ} \mathrm{C}$ for $2 \mathrm{~h}$ as detailed in the previous report [5].

\subsection{Cells Apoptosis Detection}

Cell apoptosis was determined by using Muse ${ }^{\mathrm{TM}}$ Annexin V \& Dead Cell Reagent (EMD Millipore, Billerica, MA, USA) according to the manufacturer's instructions. H157 cells were seeded at $1.5 \times 10^{5}$ cells $/ \mathrm{mL}$ in a 12-well plate and incubated overnight in a humidified atmosphere containing at $37^{\circ} \mathrm{C}$ under $5 \% \mathrm{CO}_{2}$. After which, cells were treated with 1, 10 and $100 \mu \mathrm{M}$ F-SL for $8 \mathrm{~h}$. Positive control groups were treated with $200 \mu \mathrm{M}$ carboplatin for the same time. After treatment, the growth medium was removed and cells washed with ice-cold PBS twice and centrifuged at $300 \times g$ for 3 min at $4{ }^{\circ} \mathrm{C}$ and re-suspended by growth medium. Cell suspension $(100 \mu \mathrm{L})$ was stained with $100 \mu \mathrm{L}$ Muse Annexin V \& Dead Cell Reagent for $20 \mathrm{~min}$ at room temperature protect from light and the suspension was analysed using Muse Cell Analyzer (EMD Millipore, Billerica, MA, USA).

\subsection{Caspase 3/7 Activity Assay}

Caspase 3/7 activity was determined by using MUSE ${ }^{\mathrm{TM}}$ Caspase-3/7 Kit (EMD Millipore, Billerica, MA, USA) according to the manufacturer's instructions. For the caspase 3/7 activity detection, $\mathrm{H} 157$ cells were seeded at $1.5 \times 10^{5}$ cells $/ \mathrm{mL}$ in a 12-well plate and allowed to attach overnight in a humidified atmosphere containing $5 \% \mathrm{CO}_{2}$ at $37^{\circ} \mathrm{C}$. After which, cells were treated with 1,10 and $100 \mu \mathrm{M}$ peptide for $24 \mathrm{~h}$. Positive control groups were treated with $200 \mu \mathrm{M}$ carboplatin for the same time. After treatment, growth medium was removed and cells were twice washed with ice-cold PBS and centrifuged at $300 \times g$ for $3 \mathrm{~min}$ at $4{ }^{\circ} \mathrm{C}$ and re-suspended by $1 \times$ assay buffer, stained with MUSE Caspase-3/7 reagent for $30 \mathrm{~min}$ at $37^{\circ} \mathrm{C}$. Then mixed the cell with the 7-AAD reagent and analysed using Muse Cell Analyzer (EMD Millipore, Billerica, MA, USA). 


\subsection{Modelling and Molecular Docking Analysis}

The peptide sequences of SL-BBI and its analogue obtained by molecular cloning and structural identification were submitted to the I-TASSER server (https://zhanglab.ccmb.med.umich.edu/I-TASSER/) for three-dimensional (3D) structure modelling [27]. The 3D structure of the yeast 20S proteasome (PDB ID: 2F16) comes from the protein database bank (PDB) (https://www.rcsb.org/) and the targeted subunits were separated. To simulate the main binding conditions between the ligand peptide (F-SL) and the receptor protein ( $\beta 1$ and $\beta 5$ subunits) with a known 3D structure, the water molecules and the original ligand in the structure of the candidate docking complex were eliminated. Then the Z-DOCK server (http://zdock.umassmed.edu/) was used to perform rigid molecular docking on all receptor molecules and ligand. ZDOCK will search all the translation and rotation spaces of the receptor and ligand molecules and then use energy-based functions to score each possible pose, which includes potential energy, space complementation and electric field force in the calculations. [28,29]. The highest-ranked ZDOCK pose was selected and Accelrys Discovery Studio software (Biovia, San Diego, CA, USA) was used for the visualization of interaction structures.

\subsection{Statistical Analysis}

Each data point averaged by three independent experiments and expressed as means \pm standard error (SEM). All of the data were statistically analysed by Prism 6 (GraphPad Prism Software, GraphPad, SanDiego, CA, USA) and one-way analysis of variance (ANOVA) of the differences. $p<0.05$ was considered to be significant.

\section{Results}

\subsection{Identification and Structural Characterisation of SL-BBI}

The cDNA encoding the biosynthetic precursor of a trypsin inhibitory peptide was successfully cloned from the skin secretion-derived cDNA library of Sylvirana latouchii and was named SL-BBI. After fractionated of lyophilised skin secretions by RP-HPLC, the molecular mass of each fraction was identified by MALDI-TOF MS and the elution site of SL-BBI was confirmed (Figure 1a). The primary structure of this novel peptide was subsequently confirmed by MS/MS fragmentation sequencing (Figure $1 \mathrm{~b}$ and Figure S1). The open reading frame of SL-BBI was made up of 192 base pairs encoding 63 amino acids (Figure 1c). The putative signal peptide was composed of 22 amino acids and the mature peptide with 17 amino acids was processed at a classical propeptide convertase cleavage site (-KR-) following an acidic residue rich residue. Simulated structure of SL-BBI in stick model showed a similar configuration to peptide HV-BBI (PDB ID: 4U2W) which belongs to the Ranacyclin family (Figure 1d). The sequence of the mature peptide was searched and analysed by the Basic Local Alignment Search Tool (BLAST) program on NCBI and showed obvious similarity with amphibian-derived Bowman-Birk type inhibitory peptides (Figure 2). The nucleotide sequence of cDNA precursor of SL-BBI was deposited in the Genbank Database under an accession number: MT756002. 


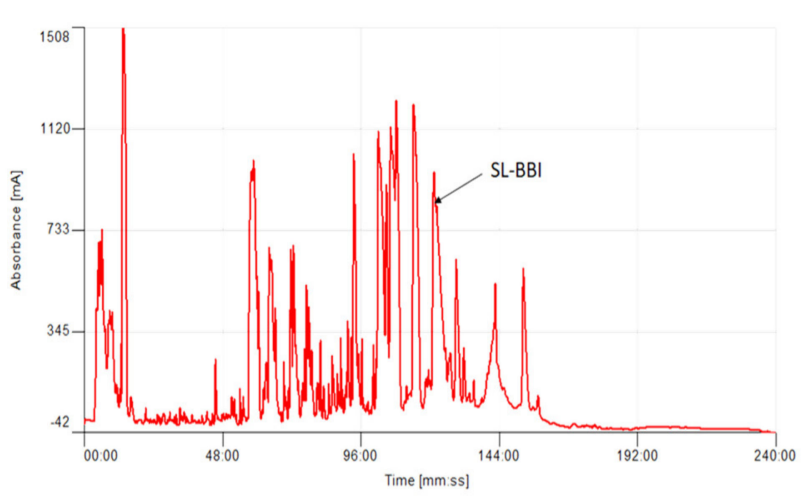

(a)

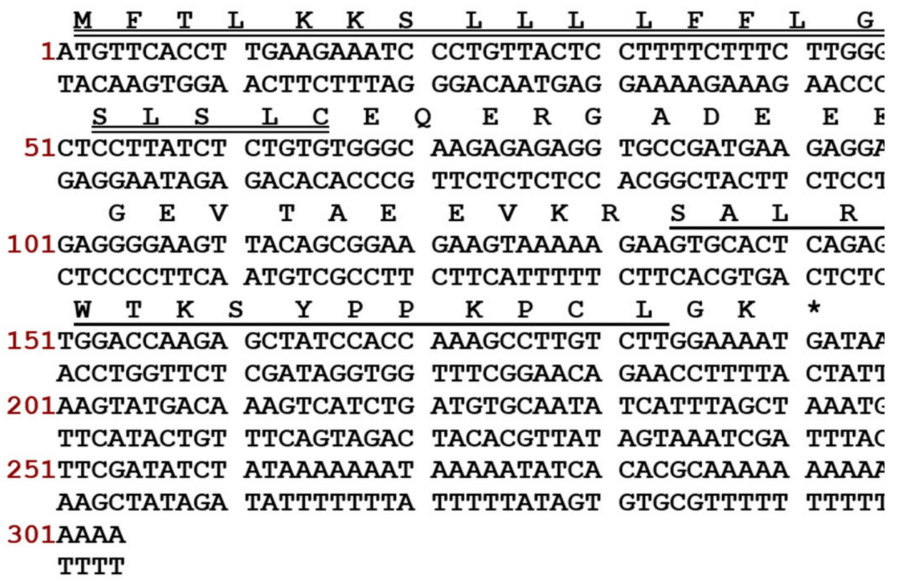

(c)

\begin{tabular}{|c|c|c|c|c|c|}
\hline$\# 1$ & $b(1+)$ & $b(2+)$ & Seq. & $y(1+)$ & $y(2+)$ \\
\hline 1 & 88.03931 & 44.52329 & $s$ & & \\
\hline 2 & 159.07643 & 80.04185 & A & 1818.95066 & 909.978 \\
\hline 3 & 272.16050 & 136.58389 & L & 1747.91354 & 874.460 \\
\hline 4 & 428.26162 & 214.63445 & $R$ & 1634.82947 & 817.918 \\
\hline 5 & 485.28309 & 243.14518 & G & 1478.72835 & 739.867 \\
\hline 6 & 588.29228 & 294.64978 & c & 1421.70688 & 711.357 \\
\hline 7 & 774.37160 & 387.68944 & W & 1318.69769 & 659.852 \\
\hline 8 & 875.41928 & 438.21328 & $T$ & 1132.61837 & 566.812 \\
\hline 9 & 1003.51425 & 502.26076 & k & 1031.57069 & 516.288 \\
\hline 10 & 1090.54628 & 545.77678 & s & 903.47572 & 452.241 \\
\hline 11 & 1253.60960 & 627.30844 & Y & 816.44369 & 408.725 \\
\hline 12 & 1350.66237 & 675.83482 & P & 653.38037 & 327.193 \\
\hline 13 & 1447.71514 & 724.36121 & P & 556.32760 & 278.667 \\
\hline 14 & 1575.81011 & 788.40869 & K & 459.27483 & 230.141 \\
\hline 15 & 1672.86288 & 836.93508 & $\mathrm{P}$ & 331.17986 & 166.093 \\
\hline 16 & 1775.87207 & 888.43967 & c & 234.12709 & 117.567 \\
\hline 17 & & & L-Amidated & 131.11790 & 66.062 \\
\hline
\end{tabular}

(b)

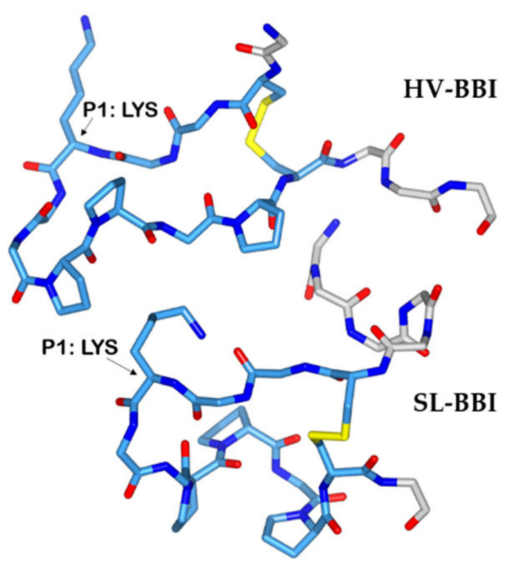

(d)

Figure 1. Identification and structural features of SL-BBI. (a) Region of RP-HPLC chromatogram of Sylvirana latouchii skin secretion with the elution position of the SL-BBI indicated by a labelled arrow. (b) Electrospray ion-trap MS/MS fragmentation data derived from fragment ions corresponding in molecular mass to SL-BBI. Predicted singly and doubly charged b-ions and y-ions are in black typeface. Ions detected by MS/MS fragmentation are indicated in red and blue. (c) Nucleotide and translated amino acid sequence of SL-BBI which cloned from the skin secretion-derived library of Sylvirana latouchii. The putative signal sequences are double-underlined, the mature sequences are single-underlined and an asterisk indicates the stop codon. (d) Comparison of the structure of HV-BBI and simulated SL-BBI in stick model (CPK colouring, with carbon atoms inside the canonical loop in light blue and outside in grey). The LYS residue at the P1 site was additionally annotated.

SL-BBI

Ranacyclin-T

Ranacyclin-Ca

Nigroain-A
Cleavage site

$\downarrow$ Amide donor MFTLKKSLLLLFFLGTISLSLCEQERGADEEENGGEVTAEEVKRSALRGCWTKSYPPKPCLGKMFTMKKTLLVLFFLGVVSLSLCVEERDAD-EEDGGEVMEEEVKRGALRGCWTKSYPPKPCKGKMFTLKKSLLHLFFLGI ISLSLCEQERDANDEEDGGEVTKEVVKRS-LRGCWTKSYPPQPCLGKR MFTMKKSLLLLFFLGIVSLSLCGQERDAD-EEDGGEVTVEEVKRSALVGCWTKSYPPKPCFGRG

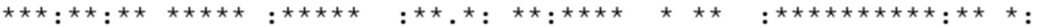

Figure 2. Alignments of partial translated amino acids sequences of Ranacyclin peptides. Ranacyclin T, Ranacyclin Ca and Nigroain-A were identified from Rana temporaria, Lithobates catesbeianus and Sylvirana nigrovittata, respectively [2,30]. Amino acid sequences aligned in ClustalW format were analysed by Clustal W2 multiple sequence alignment program. Asterisk, colons and periods indicate the conservation of residues from high to low. 


\subsection{Motif-Targeted Peptide Design and Synthesis}

Two analogues K-SL and F-SL were designed and synthesised according to the wild structure of SL-BBI with a disulphide bond formed between C6 and C16 (Table 1). Molecular mass of three synthetic peptide were observed by MALDI-TOF mass spectrometry in Figure S2. The purpose of the modification of K-SL is to promote its antimicrobial activity. The substitution of alanine (A) and lysine (K) at the head and tail increased the net positive charge and enhanced its selectivity for negatively charged bacterial cell membranes. The P1 site within the active disulphide loop of the peptides from BBI family is considered to be the most critical marker for binding to the specific S1 substrate pocket of the target enzyme, which located between the highly conserved Thr and Ser residues. The substitution of phenylalanine (F) in P1 site within the active disulphide loop was designed to enhance its chymotrypsin inhibitory and antiproliferative activity and showed the higher GRAVY than SL-BBI. The mass and purity of the synthetic peptides were determined by MALDI-TOF MS and RP-HPLC.

Table 1. Sequences and physicochemical properties of SL-BBI and its designed analogues.

\begin{tabular}{|c|c|c|c|c|c|}
\hline Peptides & Sequence & Net Charge & GRAVY $^{1}$ & Theoretical Mass (Da) & Observed Mass (Da) \\
\hline SL-BBI & SALRGCWTKSYPPKPCL-NH 2 & +4 & -0.447 & 1904.34 & 1904.60 \\
\hline K-SL & AALRGCWTKSIPPKPCK-NH & +5 & -0.406 & 1853.33 & 1851.88 \\
\hline F-SL & SALRGCWTFSIPPKPCL-NH & +3 & 0.288 & 1873.32 & 1873.82 \\
\hline
\end{tabular}

${ }^{1}$ GRAVY: Grand average of hydropathicity.

\subsection{Secondary Structure Prediction of SL-BBI and Its Analogues}

The secondary structure was analysed by using CD spectroscopy. SL-BBI and its analogues formed similar secondary structures in 50\% TFE/10 mM ammonium acetate buffer and $10 \mathrm{mM}$ ammonium acetate buffer (Figure 3). The percentage of secondary structure type of different peptide in each solvent environment was calculated (Table 2). See the secondary structure of these peptides are mostly composed of $\beta$-sheet and random coil in the neutral solvent. However, there is an increase of the helix structure of K-SL in the simulated hydrophobic cell membrane environment.
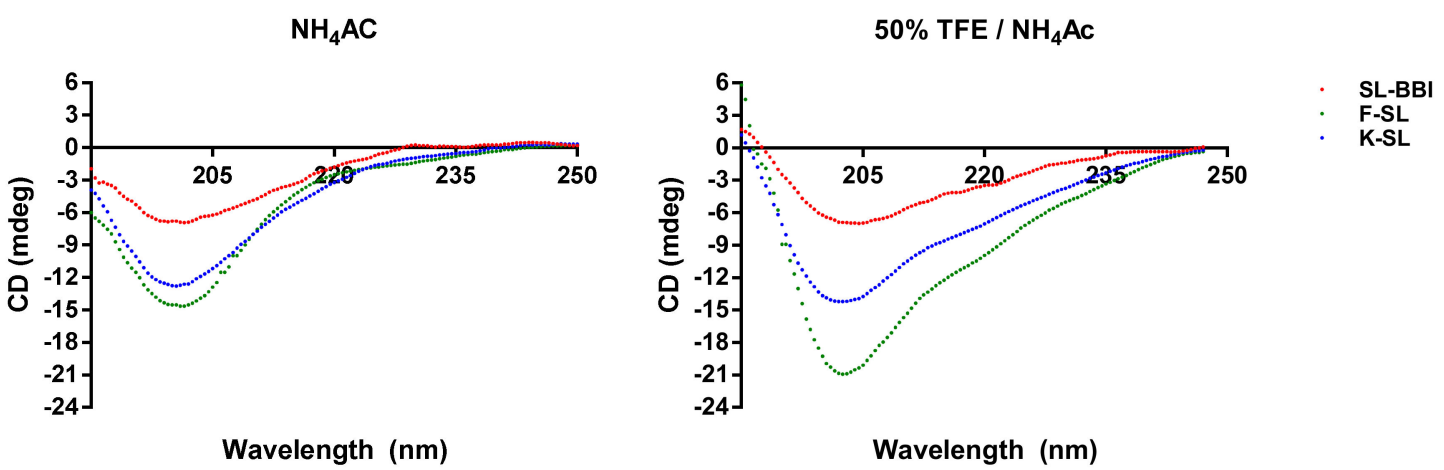

Figure 3. Circular dichroism spectra of SL-BBI (coloured red), K-SL (coloured green) and F-SL (coloured blue) $(100 \mu \mathrm{M})$ in aqueous ammonium acetate buffer and membrane mimic 50\% TFE/10 $\mathrm{mM}$ ammonium acetate buffer.

Table 2. The proportion of different secondary structures domain (\%) was predicted by using the online software, BeStSel (Beta Structure Selection).

\begin{tabular}{ccccccc}
\hline \multirow{2}{*}{ Peptides } & \multicolumn{3}{c}{$\mathbf{N H}_{\mathbf{4}} \mathrm{AC}$} & \multicolumn{3}{c}{$\mathbf{5 0 \% \mathrm { TFE } / \mathbf { N H } _ { \mathbf { 4 } } \mathrm { AC }}$} \\
\cline { 2 - 7 } & Helix & Antiparallel & Others & Helix & Antiparallel & Others \\
\hline SL-BBI & 13 & 33 & 54 & 23 & 32 & 45 \\
K-SL & 15 & 38 & 47 & 29 & 26 & 45 \\
F-SL & 13 & 40 & 47 & 13 & 36 & 51 \\
\hline
\end{tabular}




\subsection{Trypsin and Chymotrypsin Inhibitory Activity}

The inhibition effects were evaluated through trypsin and chy \pm motrypsin. The substrate hydrolysis progress curve and corresponding Morrison Ki plot were shown in Figure 4. SL-BBI exhibited potent inhibition activity to trypsin with a Ki value of $230.5 \pm 16.75 \mathrm{nM}$ while K-SL showed promote efficiency with a Ki value of $77.27 \pm 12.31 \mathrm{nM}$. The substitution of Phe in P1 position conferred F-SL on chymotrypsin inhibitory effect with a Ki value of $309.3 \pm 27.65 \mathrm{nM}$ but lost the trypsin inhibitory activity.
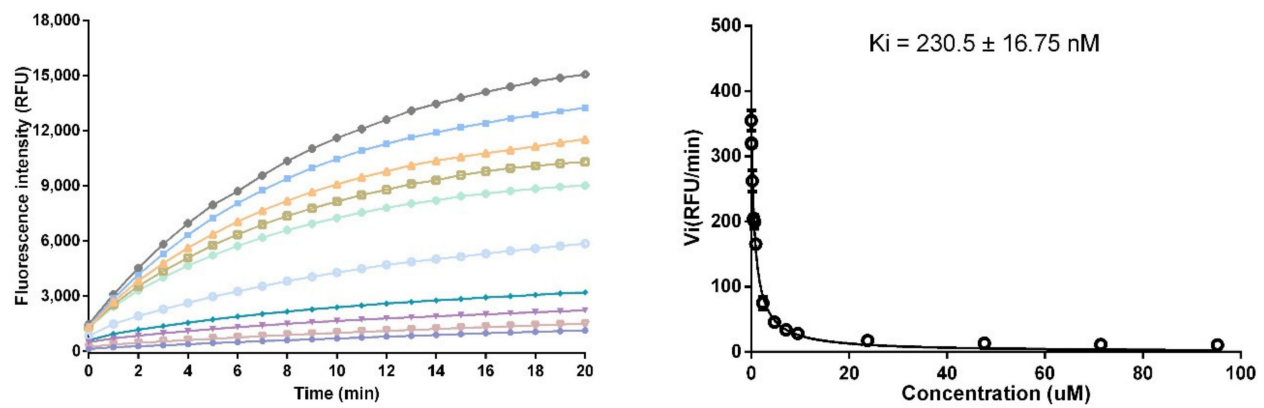

(a)
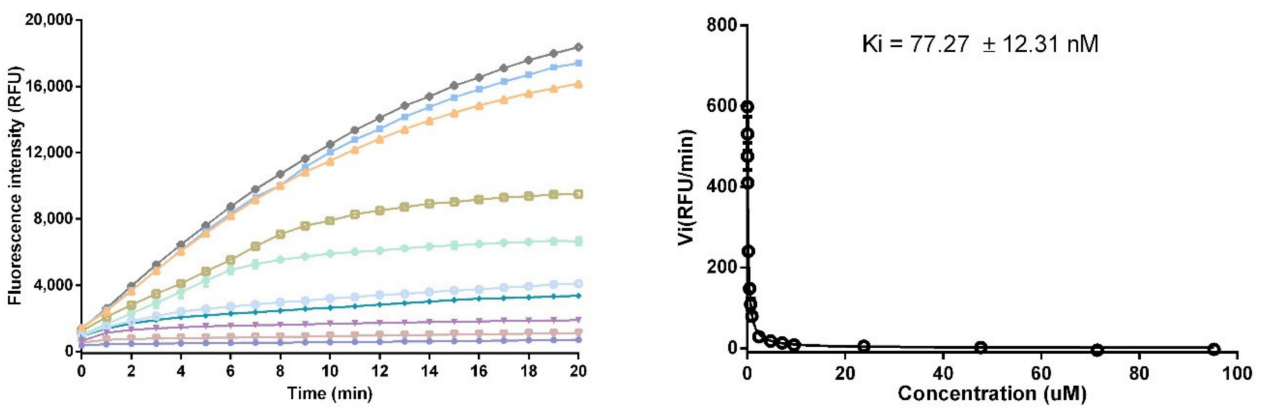

(b)
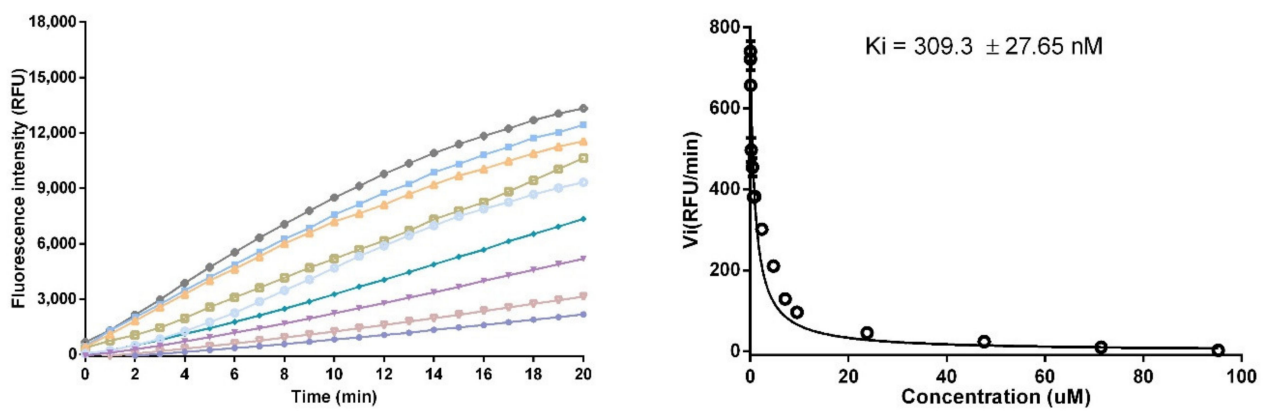

(c)

Figure 4. Inhibitory effect of SL-BBI, K-SL and F-SL on trypsin and chymotrypsin. (a) Progress curves for trypsin proteolysis under SL-BBI and corresponding Morrison Ki plot performed via final steady-state rates (Vi). (b) Progress curves for trypsin proteolysis under K-SL and corresponding Morrison Ki plot. (c) Progress curves for chymotrypsin proteolysis under F-SL and corresponding Morrison Ki plot. Data points were fitted to the curve by non-linear regression analysis, using GraphPad Prism. $(\bullet 23.81 \mu \mathrm{M}, \nabla 7.143 \mu \mathrm{M}, \nabla 4.762 \mu \mathrm{M}, \diamond 2.381 \mu \mathrm{M}, \quad 0.9542 \mu \mathrm{M}, \diamond 0.7143 \mu \mathrm{M}, \backsim 0.4762 \mu \mathrm{M}, \triangle 0.2381 \mu \mathrm{M}$, $0.02381 \mu \mathrm{M}, \diamond 0 \mu \mathrm{M})$. 


\subsection{Antimicrobial and Haemolytic Activity}

The inhibition capacities of SL-BBI, K-SL and F-SL on representative microorganisms were shown in Figure S3 and Table 3. Compared with SL-BBI, K-SL performed comprehensive improvement in the inhibitory capability against $S$. aureus and C. albicans but no promotion in E. coli and MRSA. However, F-SL completely lost antimicrobial activity. All three peptides maintained low haemolytic activity in horse erythrocytes (Figure 5).

Table 3. Antimicrobial effect of SL-BBI and its analogues against tested microorganisms.

\begin{tabular}{ccccc}
\hline \multirow{2}{*}{ Peptides } & \multicolumn{4}{c}{ MIC/MBC $(\mu \mathrm{M})$} \\
\cline { 2 - 5 } & S. aureus & E. coli & C. albicans & MRSA \\
\hline SL-BBI & $256 / 256$ & $128 / 128$ & $256 / 256$ & $>512$ \\
K-SL & $64 / 64$ & $128 / 128$ & $64 / 64$ & $>512$ \\
F-SL & $>512$ & $>512$ & $>512$ & $>512$ \\
\hline
\end{tabular}

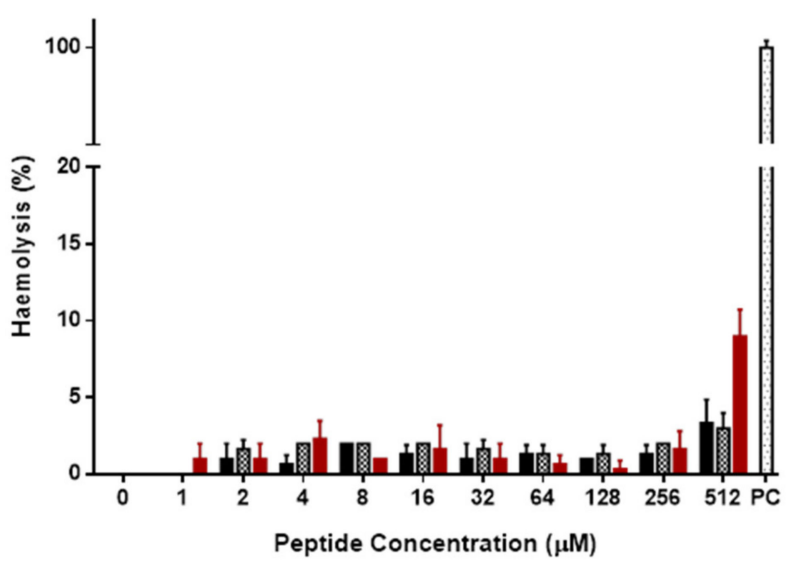

Figure 5. The hemolytic effect of SL-BBI, K-SL and F-SL against horse erythrocytes after $2 \mathrm{~h}$ incubation. The positive control group was incubated with $1 \%(v / v)$ Triton X-100. The error bar represents the S.E.M. (standard error of the mean) of 5 replicates.

\subsection{Anti-Proliferation Activity on Human Cancer and Normal Cells}

SL-BBI, K-SL and F-SL were subjected to MTT cell viability assays on series of human non-small cell lung cancer (NSCLC) cell lines (H157, H460, H838 and H23) and other cancer cell lines (PC-3, U251MG and MCF-7). As shown in Figure 6a, chymotrypsin inhibitor F-SL exhibited reinforced anti-proliferation effect on PC-3 and MCF-7 compared with other two trypsin inhibitors, especially on a series of NSCLC cells. Its toxicity to HMEC-1 was mildly enhanced but remained at a slight level at tested concentrations. The IC50 value of F-SL in Table 4 represented mean \pm S.D. (standard deviation) calculated from 3 independent experiments. Correspondingly, LDH release level under sufficient concentrations was tested as the index of cell membrane integrity. Contrary to the MTT results, F-SL did not show the ability to lyse cell membranes in any kind of cancer cells (Figure 6b). 

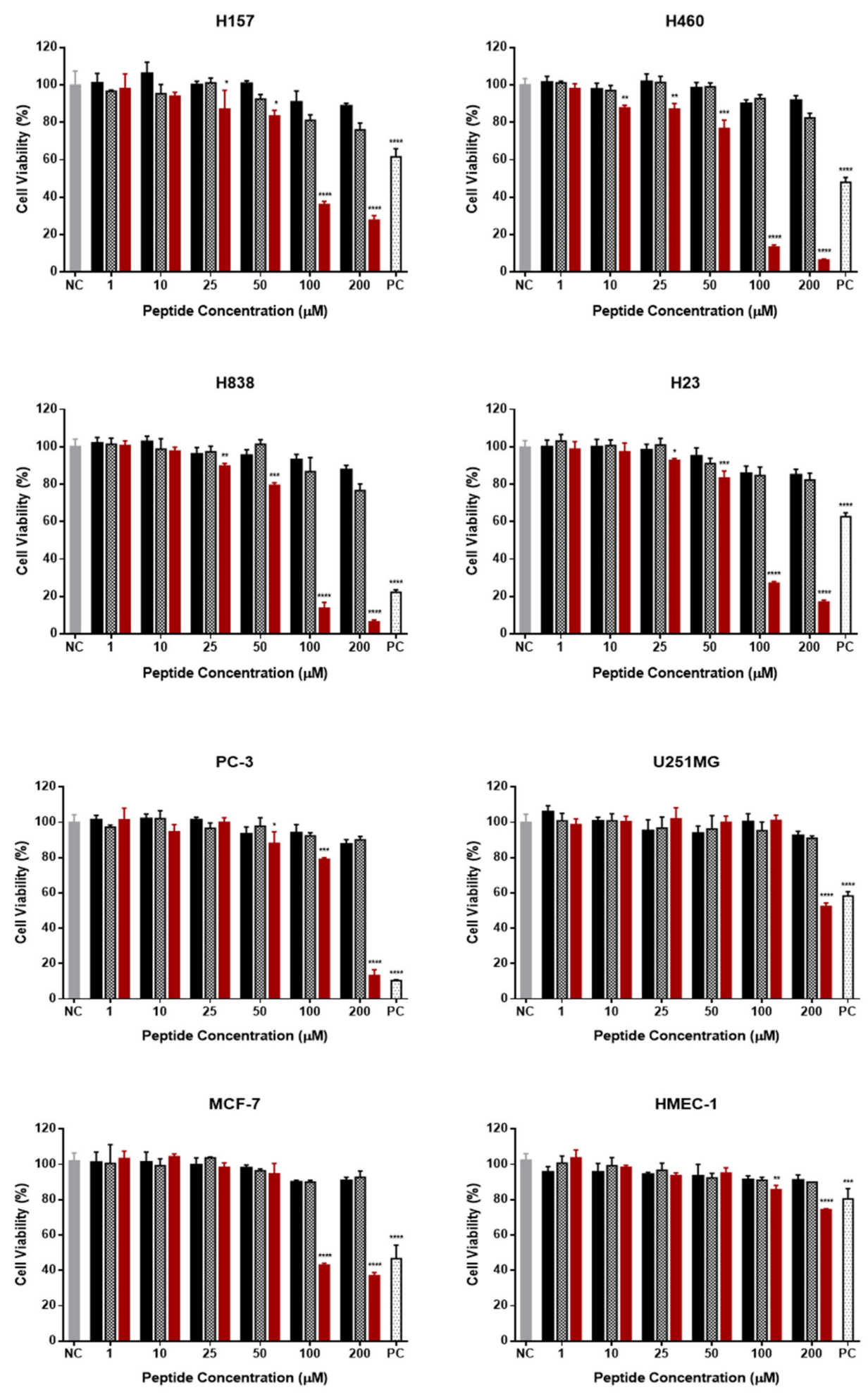

NC SL-BBI K-SL F-SL 置 PC

(a)

Figure 6. Cont. 


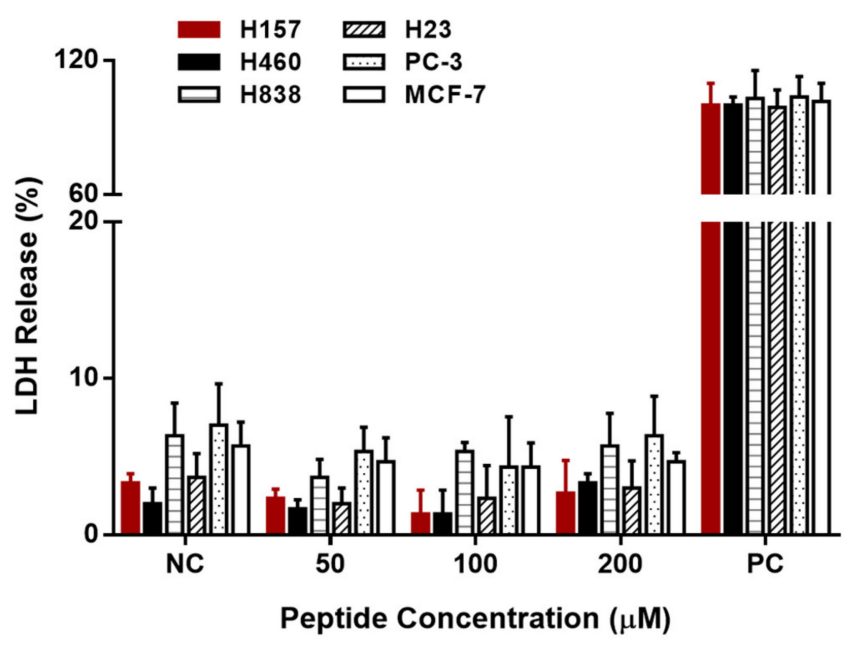

(b)

Figure 6. Cytotoxicity evaluation of SL-BBI and its analogues on different cell lines. (a) The MTT cell viability test on H157, H460, H838, H23, PC-3, U251MG, MCF-7, HCT-116 and HMEC-1 cells under different concentration after $24 \mathrm{~h}$ treatment. The $100 \%$ cell viability was applied with growing cells without peptides and a positive control group was treated with $1 \mathrm{mM} 5$-FU. (b) The LDH cytotoxicity results of F-SL on H157, H460, H838, H23, PC-3 and MCF-7. The 100\% LDH release of the positive control group was applied with 1\% Triton X-100 and negative control group was acquired after treated with culture medium. The error bar represents the S.E.M. (standard error of the mean) of 9 replicates and the levels of significance are: ${ }^{*} p<0.05,{ }^{* *} p<0.01,{ }^{* * *} p<0.001,{ }^{* * * *} p<0.0001$.

Table 4. The calculated IC50 values of F-SL on different human cell lines based on MTT results.

\begin{tabular}{cccccccc}
\hline \multirow{2}{*}{ Peptides } & \multicolumn{7}{c}{ IC50 $(\mu \mathrm{M})$} \\
\cline { 2 - 7 } & H157 & H460 & H838 & H23 & PC-3 & MCF-7 & HMEC-1 \\
\hline F-SL & $101.4 \pm 1.74$ & $65.99 \pm 2.64$ & $59.74 \pm 2.72$ & $79.06 \pm 6.41$ & $158.6 \pm 6.44$ & $201.7 \pm 10.6$ & $573.5 \pm 9.41$ \\
\hline
\end{tabular}

\subsection{F-SL Exerts Anti-Cancer Effect by Apoptosis}

To determine the mechanism of cell deaths, the Annexin V/7-AAD and Caspase 3/7 cell apoptosis detection were carried out on F-SL-treated H157 and H838 cells by flow cytometry. The phosphatidylserine (PS) present on the inner surface of the cell membrane outward to the surface is a common phenomenon in early and late apoptotic cells. Annexin V is a Ca+-dependent binding protein with high affinity for PS, which is often used in combination with nucleic acid dyes to distinguish live cells, apoptotic cells and dead cells.

Compared with the non-treated control group, F-SL treatment significantly increase the percentage of H157 and H848 cells in Annexin V (+)/7-AAD (-) and Annexin V (+)/7-AAD (+) categories (Figure 7a,c). For H157, total apoptotic cells increased to $16.09 \%(1 \mu \mathrm{M}), 17.98 \%(10 \mu \mathrm{M})$ and $35.42 \%$ $(100 \mu \mathrm{M})$ from $14.29 \%$ (negative control) after $8 \mathrm{~h}$ incubation. Similarly, the results of Caspase 3/7 activity test showed that F-SL can induce the increased the percentage of H157 cells in caspase 3/7 $(+) / 7-A A D(-)$ and caspase 3/7 (+)/7-AAD (+) categories (Figure 7b), which increased total apoptotic cells from $7.26 \%$ (negative control) to $23.95 \%(1 \mu \mathrm{M}), 26.54 \%(10 \mu \mathrm{M})$ and $39.84 \%(100 \mu \mathrm{M})$. For H838, total apoptotic cells increased to $19.64 \%(1 \mu \mathrm{M}), 21.39 \%(10 \mu \mathrm{M})$ and $37.52 \%(100 \mu \mathrm{M})$ from $8.28 \%$ (negative control) after $8 \mathrm{~h}$ incubation. Correspondingly, the results of Caspase $3 / 7$ activity test indicated that F-SL can induce the increased the percentage of H838 cells in caspase 3/7 (+)/7-AAD (-) and caspase 3/7 (+)/7-AAD (+) categories (Figure 7d), which increased total apoptotic cells from 5.08\% (negative control) to $12.79 \%(1 \mu \mathrm{M}), 48.75 \%(10 \mu \mathrm{M})$ and $57.62 \%(100 \mu \mathrm{M})$. The assessment of apoptosis by Annexin V and Caspase3/7 assay indicated that F-SL leads to programmed death of H157 and H838 cells in a dose-dependent manner. 




$1 \mu \mathrm{M}$ F-SL



Negative control

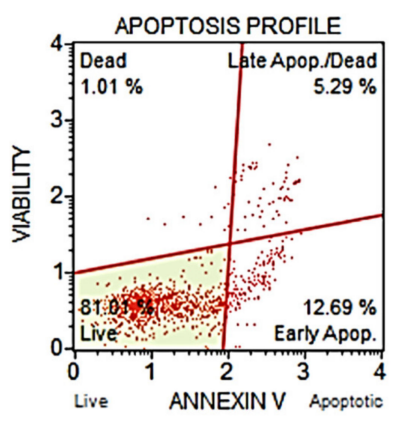

$10 \mu \mathrm{M}$ F-SL



Positive control

(a)

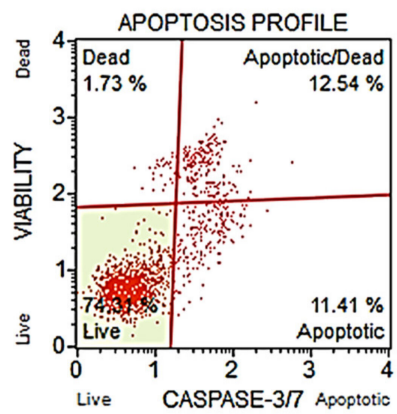

$1 \mu \mathrm{M}$ F-SL

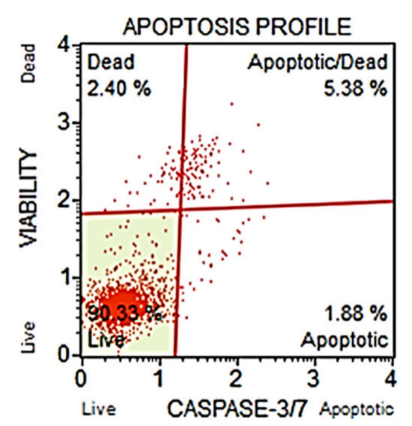

Negative control

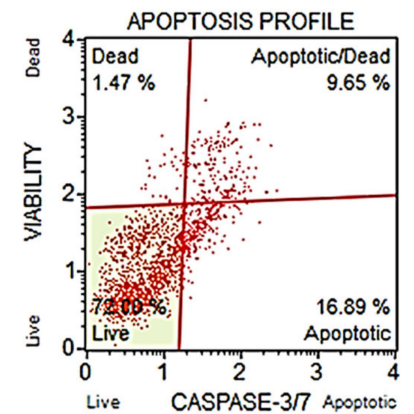

$10 \mu \mathrm{M}$ F-SL

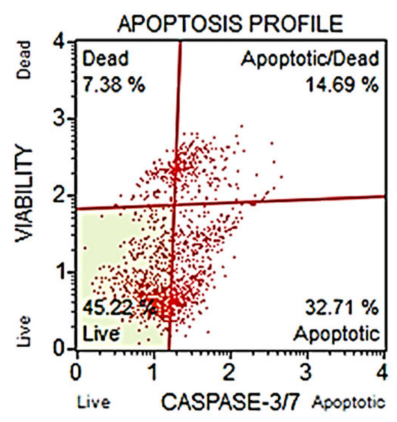

Positive control

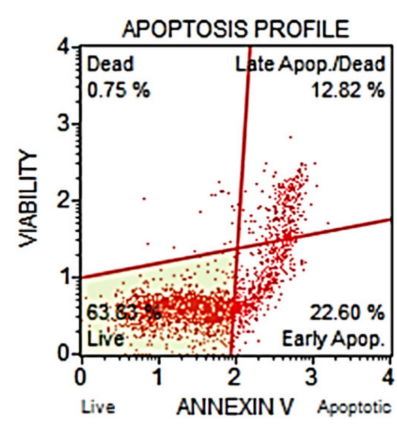

$100 \mu \mathrm{M}$ F-SL

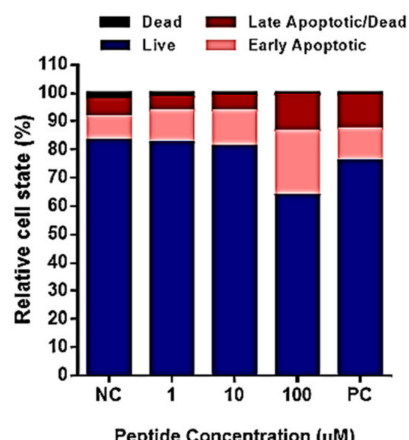

Peptide Concentration ( $\mu \mathrm{M})$



$100 \mu \mathrm{M}$ F-SL

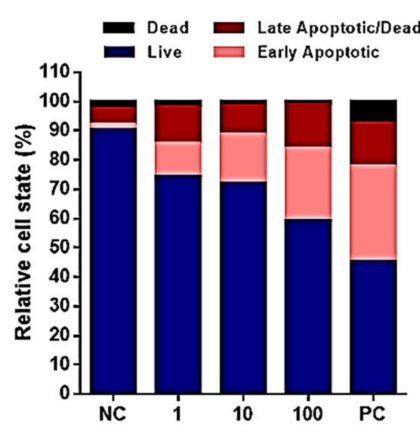

Peptide Concentration ( $\mu \mathrm{M})$

(b)

Figure 7. Cont. 


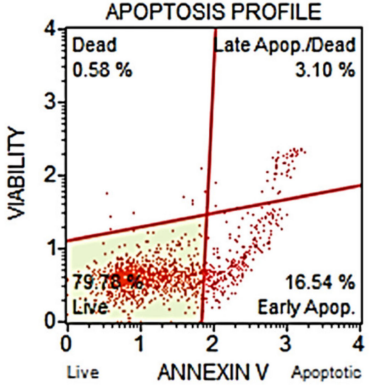

$1 \mu \mathrm{M}$ F-SL

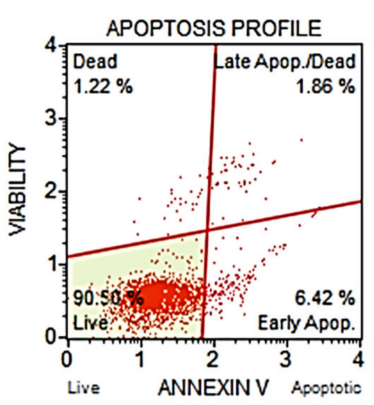

Negative control



$10 \mu \mathrm{M}$ F-SL

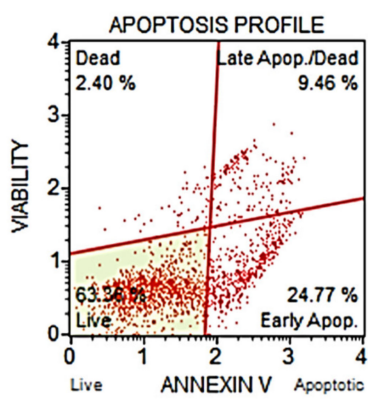

Positive control

(c)

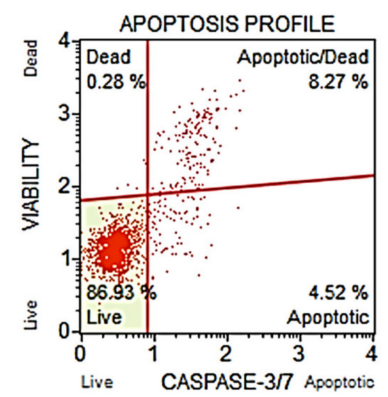

$1 \mu \mathrm{M}$ F-SL

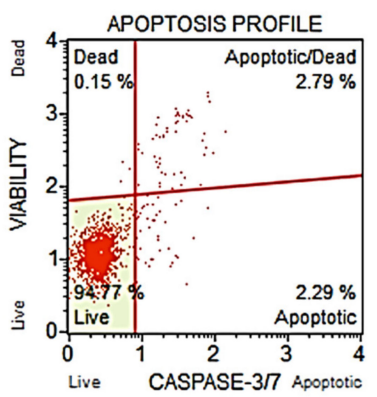

Negative control

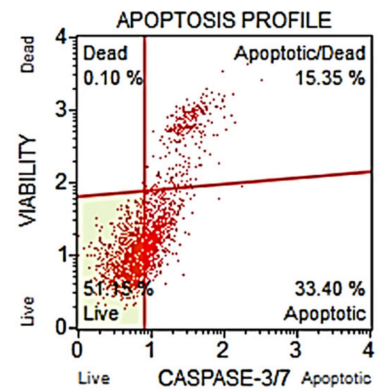

$10 \mu \mathrm{M}$ F-SL

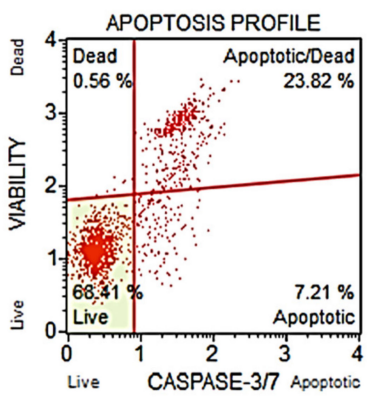

Positive control

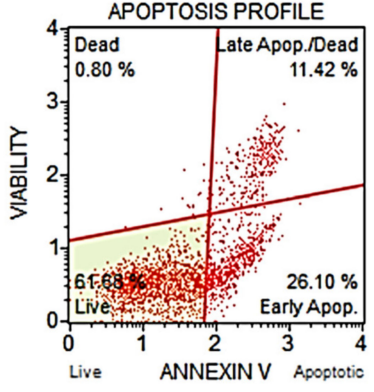

$100 \mu \mathrm{M}$ F-SL

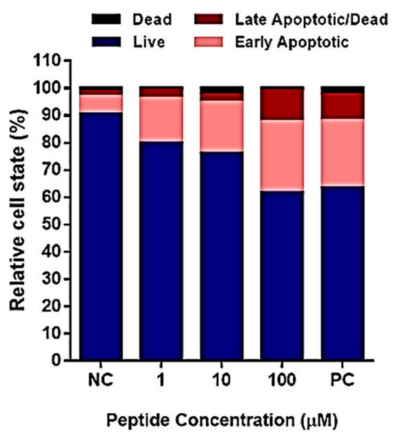



$100 \mu \mathrm{M}$ F-SL

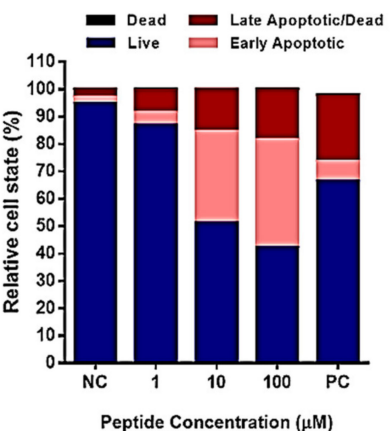

(d)

Figure 7. Assessment of apoptosis and relative state percentage in $\mathrm{H} 157$ and $\mathrm{H} 838$ cell lines induced by F-SL of different concentrations. (a) Representative plots from Annexin V-FITC/7-AAD assay after $8 \mathrm{~h}$ incubation on H157. (b) Representative plots from Caspase 3/7/7-AAD assay $16 \mathrm{~h}$ incubation on H157. (c) Representative plots from Annexin V-FITC/7-AAD assay after $8 \mathrm{~h}$ incubation on H838. (d) Representative plots from Caspase 3/7/7-AAD assay $16 \mathrm{~h}$ incubation on H838. The gated cells with quadrant marker divided date into live, apoptotic, apoptotic/dead and dead populations. Positive drug control groups were treated with $1 \mathrm{mM} 5$-FU and negative control groups were acquired after treated with culture medium. 


\subsection{Molecular Docking Simulation of F-SL}

Accelrys Discovery Studio software was used to evaluate the amino acids and their molecules involved in H-bonding in the predicted docking model generated by the ZDOCK online server. ZDOCK obtains all possible mutual binding modes of $\beta 1 / \beta 5$ subunits in F-SL and yeast $20 \mathrm{~S}$ proteasome in space through shape complementation, and uses the energy-based scoring function to evaluate the reliability of each binding model. The most reliable models are shown in Figure 8 . The simulation results showed that the Thr1, Thr21, Gly47, Ser48 and Tyr135 residues of the beta1 subunit receptor were expected to interact with the Thr8, Gly5, Trp7 and Ser10 residues in the F-SL ligand, respectively (Figure 8a). And the Thr1, Gly47, Gly48 and Ala49 residues of the $\beta 5$ subunit receptor were expected to interact with Ser10, Phe9, Ile11 and Ser10 residues in the active loop of the F-SL ligand, respectively (Figure $8 \mathrm{~b}$ ). These results reflected our prediction of the mechanism of peptide binding from the side. F-SL may have a high affinity for the $\beta 1$ and $\beta 5$ subunits with catalytic effects in the $20 \mathrm{~S}$ core particles, thereby affecting the related cancer pathological processes regulated by the proteasome pathway.

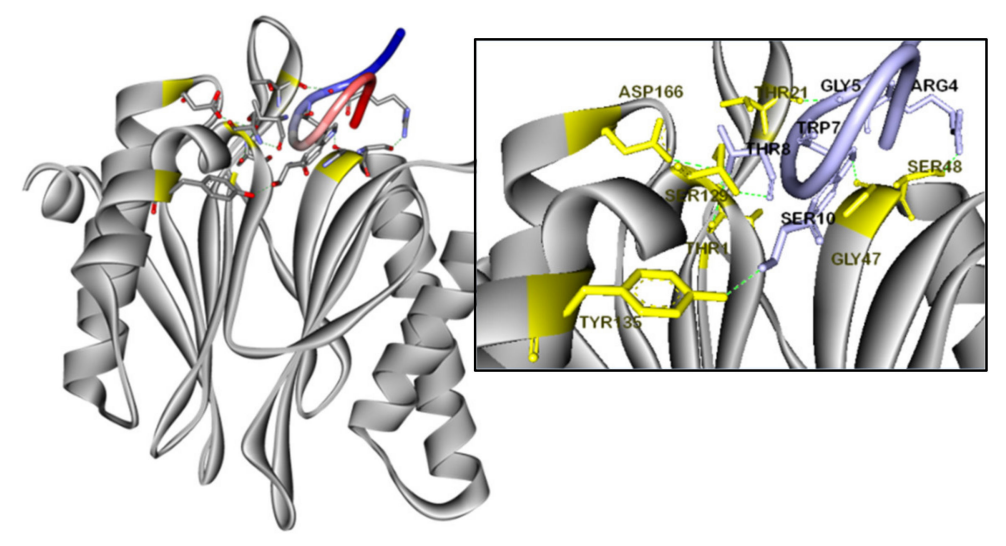

(a)

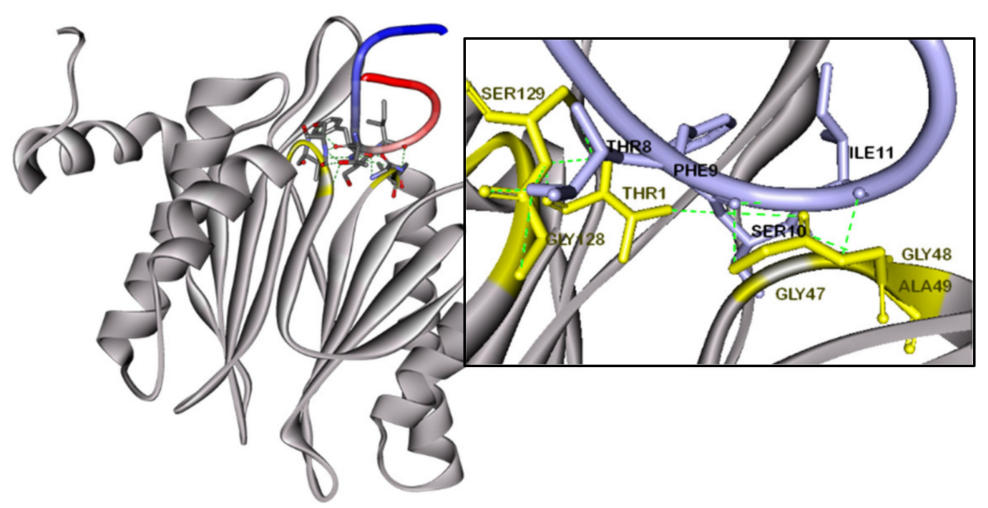

(b)

Figure 8. Simulated interaction of the protease-inhibitor docking for F-SL with $\beta 1$ (a) and $\beta 5(\mathbf{b})$ subunits of yeast $20 \mathrm{~S}$ proteasome. The residues involved in the interaction on the corresponding subunits of F-SL (N-terminus is blue and C-terminus is red) were shown in stick representation. Possible active binding sites in subunits were highlighted in yellow and the hydrogen bonds were represented by green dotted lines. 


\section{Discussion}

The active substances in amphibian skin secretions have always occupied an essential position in the field of natural drug discovery. Currently, a variety of bioactive peptides of brevinin, temporin, ranatensin, nigrocin and ranacyclin families have been discovered from broad-folded frog (Sylvirana latouchii) [31-34] and showed potential medicinal value. Here, we found a novel Bowman-Birk type trypsin inhibitor peptide from this species named SL-BBI, which shared the highly conserved '-CWTP ${ }_{1}$ SXXPKPC-' ring with the ranacyclin family. In addition to structural and functional identification, we also made target-modifications to promote its antimicrobial and anticancer capabilities.

The ranacyclin family was previously regarded as a branch of antimicrobial peptides [2]. However, as more extensive discoveries and studies have shown that its ability to inhibit serine protease is more prominent than antimicrobial [11]. SL-BBI is undoubtedly a highly effective trypsin inhibitor with a Ki value of $230.5 \mathrm{nM}$. Due to its antimicrobial performance is not satisfactory, K-SL was designed by substitution of Ala, Ile and Lys in position 1, 11 and 17, respectively. Structural changes did not excessively affect its trypsin inhibitory effect and remained at a Ki value of $77.27 \mathrm{nM}$. It is well known that rich in positively charged amino acids is one of the characteristics of antimicrobial peptides [35], which means that trypsin-like proteases that regard Lys and Arg as cleavage sites are easy to hydrolyse them. The antimicrobial effect of Ranacyclin family peptides is attributed to the increase in permeability of cytoplasmic phospholipid membranes and the formation of transmembrane pores by inserting hydrophobic cores [2,13]. This mechanism of maintaining the integrity of the cell membrane is different from most antimicrobial peptides. The substituted Ile in $\mathrm{P}_{2^{\prime}}$ site with large aliphatic side chain in the active disulphide loop provided optima packing to the apolar $S_{2}$ substrate pocket of serine proteases and retarded hydrolysis rate [36], and the replacement of N-terminal and C-terminal ends amino acids enhanced the cationicity with reference to the sequences of ORB [37] and Ranacyclin-T/E [2]. The increase of positive charges and the $\alpha$-helix structure formed in the simulated hydrophobic cell membrane environment may help K-SL act on the negative charged bacterial cell membrane. Correspondingly, K-SL showed the stronger antimicrobial effect to S. aureus and C. albicans with MIC value of $64 \mu \mathrm{M}$ but maintained the same MIC value of $128 \mu \mathrm{M}$ in E. coli with wild SL-BBI. On the contrary, the substitution of Phe at the $\mathrm{P}_{1}$ site (F-SL) resulted in a significant reduction in positive charge and loss of antimicrobial activity. In addition, SL-BBI and its analogues showed almost no haemolytic effect on horse erythrocytes even at a high concentration of $512 \mu \mathrm{M}$. This is similar to the characteristic that the cyclic pLR (belongs to Ranacyclin family) can produce strong membrane permeability for the electronegative POPG membrane but has no effect on the electrically neutral POPC membrane [38]. Some analysis pointed out that members of the Ranacyclin family with high-efficiency antibacterial activity may gather on the surface of bacterial cell membranes to form channel structures due to the strong hydrophobic phenylalanine exposed at the C-terminal [37]. The characteristic of rich in cationic residues in antimicrobial peptides predestined their sensitivity to trypsin-like proteases, which indicates that bifunctional peptides with trypsin-like inhibition and antimicrobial activities will become ideal candidates for anti-infective agents. Although the inhibitory effects are not produced in drug-resistant strains, bifunctional peptides with antimicrobial and protease inhibitory activities may become ideal candidates for a new generation of antibiotics, which can kill microorganisms while resisting degradation of proteases.

The anticarcinogenesis of BBI type inhibitors is generally considered to be more relevant with the proteasomal chymotrypsin-like activities [14,21,22], which also been proved by the discovery of HECI from the Asian green frog [5], a natural chymotrypsin inhibitor with antiproliferative effect. BBI and its concentrated products (BBIC) can not only enhance the killing effect of cisplatin on lung cancer and ovarian cancer cells and protect normal cells in vitro [39-41], but also inhibit the conversion of a series of carcinogens such as dimethylhydrazine and 3-methylcholanthrene in different organs in vivo [42,43]. The precise mechanism of protease inhibitors exhibiting anticancer activity is still widely debated, but the contribution of chymotrypsin inhibition probably indicates the influence in 
the ubiquitin-proteasome pathway (UPP) in tumor cells. UPP mediates transcriptional and apoptosis regulation by controlling crucial proteins such as the activation of caspases and NF-kB and the degradation of Bcl-2 [44,45]. As the core particle of mammalian 26 proteasomes in UPP, 20S proteasome consists of three major active subunits, $\beta 1, \beta 2$ and $\beta 5$, which assigned to different activities to caspase-like, tryptic-like and chymotryptic-like by the nature of their S1 substrate pocket $[5,46,47]$.

In this way, we designed F-SL for the distinction of specific substrate pocket of different serine proteases and used Phe at active P1 position to best match chymotrypsin-like subunit. Firstly, the substitution of Lys by Phe authentically resulted in an increase in chymotrypsin inhibitory effectiveness to a Ki value of $309.3 \mathrm{nM}$ in F-SL but lost the trypsin inhibitory activity at the same time. The docking results of this study show an excellent superposition of the $\beta 1$ and $\beta 5$ subunits in yeast $20 S$ proteasome with F-SL, which was similar to the covalent and reversible binding by classic proteasome inhibitor bortezomib with the Thr at the active sites of the $\beta 5$ subunit [48]. As the first clinical proteasome inhibitor, bortezomib was originally used in the treatment of multiple myeloma, but recent studies have shown that it can be used alone or in combination therapy for pancreatic, prostate, breast or non-small cell lung cancers [49,50]. MTT cytotoxicity test suggested that chymotrypsin inhibitor F-SL is the most potent anticancer agent with antiproliferative effect in a series of non-small cell lung cancer cell lines (H157, H460, H838 and H23), which also showed a certain inhibitory effect on prostate cancer cell PC-3 and breast cancer cell MCF-7 while SL-BBI and K-SL were totally inactive. However, F-SL was unable to cause the release of LDH in cells at a concentration with antiproliferative activity, which indicated that it will not cause cell membrane rupture and contents leakage. PS eversion of the inner surface of the cell membrane is the most commonly used basis for judging cell apoptosis. According to the significant increase in Annexin V-FITC positive cell population, we found F-SL induced apoptosis in H157 and H838 cell lines in dose-dependent manner. Caspase 3 and caspase 7 are the most important executioners in the cysteine-aspartic acid protease (caspase) family involve in cell apoptosis cascade which possess similar substrate specificity. Caspase 3/7 zymogens are inactive until hetero-activation is performed by the upstream initiator caspase 8 after apoptotic signal delivered and then degrade the cellular components in a controlled manner [51]. Therefore, F-SL-induced caspase 3/7 activation in H157 and H838 cells confirmed its induction of apoptosis. We conjectured that F-SL may have a similar mechanism of apoptosis induction as Bortezomib: inhibit the activity of proteasomes in cells and thus preventing the activation of NF-kB and Bcl-2 to enhance the cascade activation of caspase $[47,52,53]$. This inhibitory effect can also cause subsequent mitochondrial impairment and oxidative damage [14]. On the other hand, the anti-proliferative effect of F-SL on cells appears to be selective against cancer cells. Not only is it almost non-toxic to horse erythrocytes, but it also showed less antiproliferative effect on normal human endothelial cells HMEC-1. This difference may cause by abnormal protein activity in malignant cells with high proliferation. Tumor cells are more sensitive to relative inhibitors because they rely more on UPP to degrade abnormal proteins or even reverse cell cycle and apoptosis checkpoint mutations to cause tumorigenesis [47].

In summary, SL-BBI is a novel peptide with bifunction of potent trypsin inhibitory and weak antimicrobial from the skin secretion of Sylvirana latouchii which belongs to the ranacylin family. Through targeted structural modification, two analogues K-SL and F-SL with improved antimicrobial and anticancer activity were obtained respectively. F-SL with chymotrypsin inhibitory activity exhibits targeted induction of cancer cell apoptosis which involved caspase 3/7 activation. It also shows that the short cyclic peptide of the ranacyclin family is an excellent template for the development of multifunctional peptides and provide more drug candidates for cancer chemotherapy and prevention in the future.

Supplementary Materials: The following are available online at http://www.mdpi.com/2218-273X/10/9/1254/s1, Figure S1: MS/MS fragmentation data derived from fragment b- and y-ions corresponding in molecular mass to SL-BBI, Figure S2: MALDI-TOF mass spectrums of synthetic peptide SL-BBI (a), K-SL (b) and F-SL (c), Figure S3: Inhibitory effects following incubation of SL-BBI, K-SL and F-SL with S. aureus, MRSA, C. albicans and E. coli in a range of concentrations from $1 \mu \mathrm{M}$ to $512 \mu \mathrm{M}$. 
Author Contributions: Conceptualization, M.Z., C.M., T.C. and L.W.; data curation, X.C. (Xi Chen), D.C. and L.H.; formal analysis, D.C.; investigation, X.C. (Xi Chen), C.M. and T.C.; methodology, X.C. (Xiaoling Chen); supervision, X.X. and C.M.; visualization, X.C. (Xi Chen) and L.H.; writing-original draft, X.C. (Xi Chen); writing-review and editing, X.X. All authors have read and agreed to the published version of the manuscript.

Funding: This research received no external funding.

Conflicts of Interest: The authors declare no conflict of interest.

\section{References}

1. Brauer, A.B.E.; Nievo, M.; McBride, J.D.; Leatherbarrow, R.J. The Structural Basis of a Conserved P2 Threonine in Canonical Serine Proteinase Inhibitors. J. Biomol. Struct. Dyn. 2003, 20, 645-655. [CrossRef] [PubMed]

2. Mangoni, M.L.; Papo, N.; Mignogna, G.; Andreu, D.; Shai, Y.; Barra, D.; Simmaco, M. Ranacyclins, a New Family of Short Cyclic Antimicrobial Peptides: Biological Function, Mode of Action, and Parameters Involved in Target Specificity. Biochemistry 2003, 42, 14023-14035. [CrossRef] [PubMed]

3. Dong, Y.; Shi, D.; Ying, Y.; Xi, X.; Chen, X.; Wang, L.; Zhou, M.; Wu, Q.; Ma, C.; Chen, T. A Novel Kunitzin-Like Trypsin Inhibitor Isolated from Defensive Skin Secretion of Odorrana versabilis. Biomolecules 2019, 9, 254. [CrossRef] [PubMed]

4. Chilosi, G.; Caruso, C.; Caporale, C.; Leonardi, L.; Bertini, L.; Buzi, A.; Nobile, M.; Magro, P.; Buonocore, V. Antifungal Activity of a Bowman-Birk-type Trypsin Inhibitor from Wheat Kernel. J. Phytopathol. 2000, 148, 477-481. [CrossRef]

5. Zhang, L.; Chen, X.; Wu, Y.; Zhou, M.; Ma, C.; Xi, X.; Chen, T.; Walker, B.; Shaw, C.; Wang, L. A Bowman-Birk type chymotrypsin inhibitor peptide from the amphibian, Hylarana erythraea. Sci Rep. 2018, 8, 5851. [CrossRef] [PubMed]

6. Clemente, A.; Moreno, F.J.; Marín-Manzano, M.d.C.; Jiménez, E.; Domoney, C. The cytotoxic effect of Bowman-Birk isoinhibitors, IBB1 and IBBD2, from soybean (Glycine max) on HT29 human colorectal cancer cells is related to their intrinsic ability to inhibit serine proteases. Mol. Nutr. Food Res. 2010, 54, 396-405. [CrossRef]

7. Fereidunian, A.; Sadeghalvad, M.; Oscoie, M.O.; Mostafaie, A. Soybean Bowman-Birk Protease Inhibitor (BBI): Identification of the Mechanisms of BBI Suppressive Effect on Growth of Two Adenocarcinoma Cell Lines: AGS and HT29. Arch. Med. Res. 2014, 45, 455-461. [CrossRef]

8. Kennedy, A.R.; Wan, X.S. Effects of the Bowman-Birk inhibitor on growth, invasion, and clonogenic survival of human prostate epithelial cells and prostate cancer cells. Prostate 2002, 50, 125-133. [CrossRef]

9. Bogyo, M.; Souza, L.d.C.; Camargo, R.; Demasi, M.; Santana, J.M.; Sá, C.M.d.; de Freitas, S.M. Effects of an Anticarcinogenic Bowman-Birk Protease Inhibitor on Purified 20S Proteasome and MCF-7 Breast Cancer Cells. PLOS ONE 2014, 9, e86600. [CrossRef]

10. Graham, C.; Irvine, A.E.; McClean, S.; Richter, S.C.; Flatt, P.R.; Shaw, C. Peptide Tyrosine Arginine, a potent immunomodulatory peptide isolated and structurally characterized from the skin secretions of the dusky gopher frog, Rana sevosa. Peptides 2005, 26, 737-743. [CrossRef]

11. Yan, X.; Liu, H.; Yang, X.; Che, Q.; Liu, R.; Yang, H.; Liu, X.; You, D.; Wang, A.; Li, J.; et al. Bi-functional peptides with both trypsin-inhibitory and antimicrobial activities are frequent defensive molecules in Ranidae amphibian skins. Amino Acids 2011, 43, 309-316. [CrossRef] [PubMed]

12. Rakash, S. Role of proteases in cancer: A review. Biotechnol. Mol. Biol. Rev. 2012, 7, 90-101. [CrossRef]

13. Miao, Y.; Chen, G.; Xi, X.; Ma, C.; Wang, L.; Burrows, J.F.; Duan, J.; Zhou, M.; Chen, T. Discovery and Rational Design of a Novel Bowman-Birk Related Protease Inhibitor. Biomolecules 2019, 9, 280. [CrossRef] [PubMed]

14. Mehdad, A.; Brumana, G.; Souza, A.A.; Barbosa, J.; Ventura, M.M.; de Freitas, S.M. A Bowman-Birk inhibitor induces apoptosis in human breast adenocarcinoma through mitochondrial impairment and oxidative damage following proteasome $20 \mathrm{~S}$ inhibition. Cell Death Discov. 2016, 2. [CrossRef]

15. Joanitti, G.A.; Azevedo, R.B.; Freitas, S.M. Apoptosis and lysosome membrane permeabilization induction on breast cancer cells by an anticarcinogenic Bowman-Birk protease inhibitor from Vigna unguiculata seeds. Cancer Lett. 2010, 293, 73-81. [CrossRef]

16. Armstrong, W.B.; Wan, X.S.; Kennedy, A.R.; Taylor, T.H.; Meyskens, F.L. Development of the Bowman-Birk inhibitor for oral cancer chemoprevention and analysis of neu immunohistochemical staining intensity with Bowman-Birk inhibitor concentrate treatment. Laryngoscope 2010, 113, 1687-1702. [CrossRef] 
17. Kennedy, A.R. The Bowman-Birk inhibitor from soybeans as an anticarcinogenic agent. Am. J. Clin. Nutr. 1998, 68, 1406S-1412S. [CrossRef]

18. Dittmann, K.; Mayer, C.; Rodemann, H. Radioprotection of Normal Tissue to Improve Radiotherapy: The Effect of the Bowman Birk Protease Inhibitor. Curr. Med. Chem. Anti Cancer Agents 2003, 3, 360-363. [CrossRef]

19. Dittmann, K.; Mayer, C.; Kehlbach, R.; Rodemann, H.P. The radioprotector Bowman-Birk proteinase inhibitor stimulates DNA repair via epidermal growth factor receptor phosphorylation and nuclear transport. Radiother. Oncol. 2008, 86, 375-382. [CrossRef]

20. Armstrong, W.B.; Taylor, T.H.; Kennedy, A.R.; Melrose, R.J.; Messadi, D.V.; Gu, M.; Le, A.D.; Perloff, M.; Civantos, F.; Goodwin, W.J.; et al. Bowman Birk Inhibitor Concentrate and Oral Leukoplakia: A Randomized Phase IIb Trial. Cancer Prev. Res. 2013, 6, 410-418. [CrossRef]

21. Chen, Y.-W.; Huang, S.-C.; Lin-Shiau, S.-Y.; Lin, J.-K. Bowman-Birk inhibitor abates proteasome function and suppresses the proliferation of MCF7 breast cancer cells through accumulation of MAP kinase phosphatase-1. Carcinogenesis 2005, 26, 1296-1306. [CrossRef] [PubMed]

22. Clemente, A.; Gee, J.M.; Johnson, I.T.; MacKenzie, D.A.; Domoney, C. Pea (Pisum sativumL.) Protease Inhibitors from the Bowman-Birk Class Influence the Growth of Human Colorectal Adenocarcinoma HT29 Cellsin Vitro. J. Agric. Food Chem. 2005, 53, 8979-8986. [CrossRef] [PubMed]

23. Kennedy, A.R. Prevention of carcinogenesis by protease inhibitors. Cancer Res. 1994, 54, 1999s-2005s. [PubMed]

24. Álvares, A.; Schwartz, E.; Amaral, N.; Trindade, N.; Pedrino, G.; Silva, L.; de Freitas, S. Bowman-Birk Protease Inhibitor from Vigna unguiculata Seeds Enhances the Action of Bradykinin-Related Peptides. Molecules 2014, 19, 17536-17558. [CrossRef] [PubMed]

25. Chen, D.; Zhou, X.; Chen, X.; Huang, L.; Xi, X.; Ma, C.; Zhou, M.; Wang, L.; Chen, T. Evaluating the Bioactivity of a Novel Antimicrobial and Anticancer Peptide, Dermaseptin-PS4(Der-PS4), from the Skin Secretion of Phyllomedusa sauvagii. Molecules 2019, 24, 2974. [CrossRef] [PubMed]

26. Wu, Y.; Long, Q.; Xu, Y.; Guo, S.; Chen, T.; Wang, L.; Zhou, M.; Zhang, Y.; Shaw, C.; Walker, B. A structural and functional analogue of a Bowman-Birk-type protease inhibitor from Odorrana schmackeri. Biosci. Rep. 2017, 37. [CrossRef] [PubMed]

27. Yang, J.; Zhang, Y. I-TASSER server: New development for protein structure and function predictions. Nucleic Acids Res. 2015, 43, W174-W181. [CrossRef]

28. Pierce, B.G.; Wiehe, K.; Hwang, H.; Kim, B.H.; Vreven, T.; Weng, Z. ZDOCK server: Interactive docking prediction of protein-protein complexes and symmetric multimers. Bioinformatics 2014, 30, 1771-1773. [CrossRef]

29. Mintseris, J.; Pierce, B.; Wiehe, K.; Anderson, R.; Chen, R.; Weng, Z. Integrating statistical pair potentials into protein complex prediction. Proteins Struct. Funct. Bioinform. 2007, 69, 511-520. [CrossRef]

30. Ma, Y.; Liu, C.; Liu, X.; Wu, J.; Yang, H.; Wang, Y.; Li, J.; Yu, H.; Lai, R. Peptidomics and genomics analysis of novel antimicrobial peptides from the frog, Rana nigrovittata. Genomics 2010, 95, 66-71. [CrossRef]

31. Wang, H.; Yan, X.; Yu, H.; Hu, Y.; Yu, Z.; Zheng, H.; Chen, Z.; Zhang, Z.; Liu, J. Isolation, characterization and molecular cloning of new antimicrobial peptides belonging to the brevinin-1 and temporin families from the skin of Hylarana latouchii (Anura: Ranidae). Biochimie 2009, 91, 540-547. [CrossRef] [PubMed]

32. Lin, Y.; Chen, T.; Zhou, M.; Wang, L.; Su, S.; Shaw, C. Ranatensin-HL: A Bombesin-Related Tridecapeptide from the Skin Secretion of the Broad-Folded Frog, Hylarana latouchii. Molecules 2017, 22, 1110. [CrossRef] [PubMed]

33. Bao, K.; Yuan, W.; Ma, C.; Yu, X.; Wang, L.; Hong, M.; Xi, X.; Zhou, M.; Chen, T. Modification Targeting the "Rana Box" Motif of a Novel Nigrocin Peptide From Hylarana latouchii Enhances and Broadens Its Potency Against Multiple Bacteria. Front. Microbiol. 2018, 9. [CrossRef] [PubMed]

34. Lin, Y.; Hang, H.; Chen, T.; Zhou, M.; Wang, L.; Shaw, C. pLR-HL: A Novel Amphibian Bowman-Birk-type Trypsin Inhibitor from the Skin Secretion of the Broad-folded Frog, Hylarana latouchii. Chem. Biol. Drug Des. 2016, 87, 91-100. [CrossRef]

35. Giuliani, A.; Pirri, G.; Nicoletto, S. Antimicrobial peptides: An overview of a promising class of therapeutics. Open Life Sci. 2007, 2, 1-33. [CrossRef] 
36. Gariani, T.; McBride, J.D.; Leatherbarrow, R.J. The role of the P2' position of Bowman-Birk proteinase inhibitor in the inhibition of trypsin: Studies on $\mathrm{P}^{\prime}{ }^{\prime}$ variation in cyclic peptides encompassing the reactive site loop. Biochim. Biophys. Acta (BBA) Protein Struct. Mol. Enzymol. 1999, 1431, 232-237. [CrossRef]

37. Li, J.; Zhang, C.; Xu, X.; Wang, J.; Yu, H.; Lai, R.; Gong, W. Trypsin inhibitory loop is an excellent lead structure to design serine protease inhibitors and antimicrobial peptides. FASEB J. 2007, 21, 2466-2473. [CrossRef]

38. Salmon, A.L.; Cross, L.J.M.; Irvine, A.E.; Lappin, T.R.J.; Dathe, M.; Krause, G.; Canning, P.; Thim, L.; Beyermann, M.; Rothemund, S.; et al. Peptide Leucine Arginine, a Potent Immunomodulatory Peptide Isolated and Structurally Characterized from the Skin of the Northern Leopard Frog, Rana pipiens. J. Biol. Chem. 2001, 276, 10145-10152. [CrossRef]

39. Kennedy, C.W.; Donahue, J.J.; Wan, X.S. Effects of the bowman-Birk protease inhibitor on survival of fibroblasts and cancer cells exposed to radiation andcis-platinum. Nutr. Cancer 1996, 26, 209-217. [CrossRef]

40. Wan, X.S.; Hamilton, T.C.; Ware, J.H.; Donahue, J.J.; Kennedy, A.R. Growth inhibition and cytotoxicity induced by Bowman-Birk inhibitor concentrate in cisplatin-resistant human ovarian cancer cells. Nutr. Cancer 1998, 31, 8-17. [CrossRef]

41. Dittmann, K.H.; Gueven, N.; Mayer, C.; Rodemann, H.-P. Characterization of the amino acids essential for the photo- and radioprotective effects of a Bowman-Birk protease inhibitor-derived nonapeptide. Protein Eng. Des. Sel. 2001, 14, 157-160. [CrossRef] [PubMed]

42. Kennedy, A.R.; Billings, P.C.; Wan, X.S.; Newberne, P.M. Effects of Bowman-Birk Inhibitor on Rat Colon Carcinogenesis. Nutr. Cancer 2002, 43, 174-186. [CrossRef] [PubMed]

43. Witschi, H.; Espiritu, I. Development of tobacco smoke-induced lung tumors in mice fed Bowman-Birk protease inhibitor concentrate (BBIC). Cancer Lett. 2002, 183, 141-146. [CrossRef]

44. Palombella, V.J.; Rando, O.J.; Goldberg, A.L.; Maniatis, T. The ubiquitinproteasome pathway is required for processing the NF- $\mathrm{kB1}$ precursor protein and the activation of NF- $\mathrm{kB}$. Cell 1994, 78, 773-785. [CrossRef]

45. Adams, J.M.; Cory, S. The Bcl-2 apoptotic switch in cancer development and therapy. Oncogene 2007, 26, 1324-1337. [CrossRef] [PubMed]

46. Coux, O.; Tanaka, K.; Goldberg, A.L. Structure and Functions of the $20 \mathrm{~S}$ and 26S Proteasomes. Annu. Rev. Biochem. 1996, 65, 801-847. [CrossRef]

47. Adams, J. The proteasome: A suitable antineoplastic target. Nat. Rev. Cancer 2004, 4, 349-360. [CrossRef]

48. Groll, M.; Berkers, C.R.; Ploegh, H.L.; Ovaa, H. Crystal Structure of the Boronic Acid-Based Proteasome Inhibitor Bortezomib in Complex with the Yeast $20 S$ Proteasome. Structure 2006, 14, 451-456. [CrossRef]

49. Boccadoro, M.; Morgan, G.; Cavenagh, J. Preclinical evaluation of the proteasome inhibitor bortezomib in cancer therapy. Cancer Cell Int. 2005, 5, 18. [CrossRef]

50. Chen, D.; Frezza, M.; Schmitt, S.; Kanwar, J.; Dou, Q.P. Bortezomib as the First Proteasome Inhibitor Anticancer Drug: Current Status and Future Perspectives. Curr. Cancer Drug Targets 2011, 11, $239-253$. [CrossRef]

51. Shi, Y. Mechanisms of Caspase Activation and Inhibition during Apoptosis. Mol. Cell 2002, 9, 459-470. [CrossRef]

52. Matta, H.; Chaudhary, P.M. The proteasome inhibitor bortezomib (PS-341) inhibits growth and induces apoptosis in primary effusion lymphoma cells. Cancer Biol. Ther. 2014, 4, 84-89. [CrossRef] [PubMed]

53. Fennell, D.A.; Chacko, A.; Mutti, L. BCL-2 family regulation by the 20 s proteasome inhibitor bortezomib. Oncogene 2007, 27, 1189-1197. [CrossRef] [PubMed]

(C) 2020 by the authors. Licensee MDPI, Basel, Switzerland. This article is an open access article distributed under the terms and conditions of the Creative Commons Attribution (CC BY) license (http://creativecommons.org/licenses/by/4.0/). 